\title{
ANALISIS GAYA BAHASA PERSONIFIKASI \\ DALAM KUMPULAN SYAIR LAGU EBIET G. ADE
}

\author{
Syifa Deviyola ${ }^{1}$, Erlina Zahar $^{2}$, Uli Wahyuni ${ }^{3}$ \\ Program Studi Pendidikan Bahasa dan Sastra Indonesia, \\ Fakultas Keguruan dan Ilmu Pendidikan, Universitas Batanghari, \\ Jambi \\ Syifadeviyolla@gmail.com \\ ErlinaZahar@yahoo.co.id. \\ Uli09yumna@gmail.com
}

\begin{abstract}
This research is aimed at describing personification in the collection of song rhymes by Ebiet G. Ade. This research is descriptive qualitative. Descriptively, this research describes the features of personification in the collection of song rhymes by Ebiet G. Ade. The data is written form in the form of sentence which has personification in the collection of song rhymes by Ebiet G. Ade. Based on the result, it can be concluded that there are 47 quotes in the personification in the collection of song rhymes by Ebiet G. Ade. By identifying the meaning of the rhymes in Ebiet G. Ade songs, readers or listeners can understand messages that are delivered by the composer. The meaning of personification in the collection of song rhymes represent humans life, nature life, religious life, society life, politics and affection life.
\end{abstract}

Key Words: personification, meaning, rhyme

\footnotetext{
${ }^{1}$ Mahasiswa Program Studi Pendidikan Bahasa dan Sastra Indonesia, Fakultas Keguruan dan Ilmu Pendidikan, Universitas Batanghari, Jambi

${ }^{2}$ Dosen Program Studi Pendidikan Bahasa dan Sastra Indonesia, Fakultas Keguruan dan Ilmu Pendidikan, Universitas Batanghari, Jambi

${ }^{3}$ Dosen Program Studi Pendidikan Bahasa dan Sastra Indonesia, Fakultas Keguruan dan Ilmu Pendidikan, Universitas Batanghari, Jambi
} 


\section{PENDAHULUAN}

Karya sastra sebagai sarana yang menarik untuk dibaca dan di dengar. Karya sastra dijadikan sebagai media untuk menuangkan ide sastrawan ke dalam tulisannya."Karya sastra adalah ungkapan pribadi manusia yang berupa pengalaman, pemikiran, perasaan, ide, semangat keyakinan dalam suatu bentuk gambaran konkret yang membangkitkan pesona dengan alat bahasa". (Saini dalam Nurgiyantoro, 2013: 2). Karya sastra merupakan hasil ciptaan manusia yang berasal dari ide, pikiran dan perasaan yang menimbulkan efek keindahan, karena karya sastra menggunakan bahasa yang indah.

Sebagai karya seni, karya sastra dapat dijadikan oleh penulisnya sebagai sarana untuk meluapkan perasaannya. "Karya sastra merupakan emosi yang spontan" (Luxemburg dalam Wiyatmi, 2009: 15). Karya sastra memiliki keistimewaan, sebab sastrawan bebas dalam mengungkapkan segala permasalahan. Satrawan memiliki imajinasi daya khayal yang tinggi sehingga ia seringkali dengan mudah menemukan ide-ide yang secara tidak sengaja dituangkan ke dalam karya sastranya. Realitas kehidupan serta pengalaman pribadi pengarang kerap menjadi obyek dalam menciptakan karya sastra, berupa ungkapan emosi yang secara spontan dituangkan. Realitas kehidupan yang dituangkan bisa juga terjadi atau dialami oleh pengarang.

Karya sastra memiliki beberapa jenis salah satunya yaitu puisi. Puisi merupakan ungkapan perasaan, penghayatan kehidupan manusia yang diciptakan secara spontan oleh pengarang. Selain ungkapan perasaan, puisi juga merupakan hasil penghayatan kehidupan manusia yang diciptakan dari pikiran penyair.

Puisi dapat dikatakan karya sastra yang penuh dengan imajinasi sebab di dalam puisi terdapat gambaran kehidupan yang sesuai dengan pikiran atau perasaan pengarang. "Puisi adalah karya sastra yang dipadatkan, dipersingkat, dan diberi irama dengan bunyi yang padu dan pemilihan kata-kata yang kias atau imajinatif" (Waluyo, 2005: 45). Puisi akan semakin indah jika di dalamnya di dukung oleh kata-kata yang bermakna kias sebab itulah salah satu cara penyair dalam mengembangkan karyanya.

Syair dapat diartikan sebagai kreasi luapan ekspresi serta pemikiran pembuatnya. "Syair adalah jenis puisi lama yang berirama" (Wahyuni, 2014: 44). Syair biasanya digunakan untuk meluapkan hal-hal yang panjang seperti suatu cerita, nasihat ataupun kisah cinta yang berasal dari pikiran pengarang berupa kalimat yang memiliki irama senada. Syair merupakan puisi lama yang memiliki beberapa aturan dalam tulisannya. Syair mempunyai empat ciri. Pertama, setiap bait terdiri dari empat baris dan bersajak aa-a-a. Kedua, setiap baris mempunyai makna yang paling berkaitan dengan barisbaris sebelumnya. Ketiga, kebanyakan syair, menceritakan kisah yang mengandung nasihat/petuah. Keempat, setiap baris terdiri dari 8-12 suku kata.

Syair atau lirik merupakan karya sastra yang di dalamnya berisi pemikiran serta curahan hati yang disampaikan lewat nyayian. "Lagu adalah satu kesatuan musik yang terdiri atas susunan berbagai nada yang berurutan" (Fillaili dalam Adriani M, 2009: 8).

Lirik lagu dapat terbentuk dari hasil pemikiran pengarangnya yang kemudian diberi nada yang khas agar penyampaiannya lebih mudah diterima dan 
dinikmati pencinta lagu. Syair lagu yang memiliki gaya bahasa tidak biasa akan menambah keestetikaan tersendiri dalam syair lagu tersebut. Gaya bahasa dapat menjadikan suatu karya sastra bernilai lebih, dengan gaya bahasa yang indah pembaca dapat membandingkan kualitas karya yang dibacanya. "Gaya bahasa adalah bahasa indah yang digunakan untuk meningkatkan efek dengan jalan memperkenalkan serta membedakan suatu benda atau hal tertentu dengan benda atau hal lain yang lebih umum" (Tarigan, 2013: 4). Penggunaan kata-kata yang indah dalam karya sastra dapat menciptakan karya sastra menjadi lebih mengesankan bagi penikmatnya.

Gaya bahasa dapat terjadi jika adanya pemikiran serta ide seseorang yang dituangkan ke dalam tulisan, dari gaya bahasa dapat dilihat kepribadian pengarang dalam karyanya. "Gaya bahasa adalah cara mengungkapkan pikiran melalui bahasa secara khas yang memperlihatkan jiwa dan kepribadian penulis. "(Keraf, 1985: 113). Ungkapan yang disampaikan pengarang akan terlihat lebih hidup jika gaya bahasa yang digunakan merupakan gaya bahasa yang unik. Salah satunya gaya bahasa personifikasi.

Personifikasi merupakan gaya bahasa kiasan yang menggambarkan benda-benda mati atau sesuatu yang tidak bernyawa seolah-olah memiliki sifat kemanusiaan. "Personifikasi ialah jenis majas yang meletakan sifat-sifat insani kepada benda yang tidak bernyawa dan ide yang abstrak" (Tarigan, 2013: 17) penggunaan gaya bahasa di dalam syair lagu dapat menambah keestetikaan dalam suatu karya.

Syair salah satu karya sastra yang digemari oleh masyarakat umum, di kalangan remaja, dewasa hingga lanjut usia. Karena di dalam syair terdapat berbagai macam ungkapan perasaan, ideide serta pikiran manusia penikmat syair lagu biasanya banyak menyukai syair lagu yang di dalamnya terdapat ungkapan perasaan yang dapat mewakili keadaan suasana perasaan si pendengar. Penggunaan permainan kata dan bahasa yang bermakna kias merupakan cara pengarang untuk menciptakan daya tarik dan kekhasan terhadap syair lagu yang dilakukan oleh pencipta syair lagu. Sehingga penikmat syair dapat lebih hidup lagi dalam mengartikan apa yang dimaksudkan oleh pengarang. Salah satu syair lagu yang memiliki banyak gaya bahasa personifikasi yaitu terdapat pada kumpulan syair lagu Ebiet G. Ade.

Ebiet G. Ade termasuk salah satu daftar penyanyi papan atas yang memiliki kharisma besar. Beliau sangat pandai dalam mengolah kata menjadi sesuatu yang hidup dengan mengambil permasalahan realita kehidupan sehari-hari untuk di tuangkan kedalam syair lagulagunya. Ungkapan perasaan, emosi dan curahan hati masyarakat umum yang menjadi tema di dalam syair lagunya.

Penyimpangan makna bahasa yang digunakan pengarang dalam syair lagu membuat pendengar tidak bisa memaknai syair dalam sekali membaca atau mendengar syair lagu. Seperti syair yang menggunakan gaya bahasa personifikasi, karena gaya bahasa personifikasi merupakan gaya bahasa yang menjadikan benda mati seolah-olah hidup. Penelitian ini meneliti tentang bagaimana makna gaya bahasa personifikasi yang terdapat dalam kumpulan syair lagu Ebiet G. Ade Album Sketsa Rembulan Emas.b

Penelitian yang membahas tentang gaya bahasa di dalam karya sastra sudah pernah diteliti oleh peneliti lain yaitu Ani Mahmuda (2015) jurusan Pendidikan Bahasa dan sastra Indonesia Fakultas 
Keguruan dan Ilmu Pendidikan Universitas Batanghari Jambi yang berjudul Gaya Bahasa Perbandingan dalam Kumpulan Lagu Tulus Album 2014 Gajah. Maraluat (2016) jurusan Pendidikan Bahasa dan Seni Fakultas Keguruan dan Ilmu Pendidikan Universitas Jambi yang berjudul Kritik Sosial dan Gaya Bahasa dalam Syair Lagu Karya Iwan Fals Tahun 1989-2013. Ema Widiyas Prasida (2010) Jurusan Bahasa Sastra Indonesia dan Daerah Fakultas Keguruan dan Ilmu Pendidikan Universitas Muhammadiyah Surakarta yang berjudul Analisis Gaya Bahasa pada Lirik Lagu Ebie G. Ade. Ridha Ardila AR (2017) jurusan Pendidikan Bahasa dan Seni Fakultas Keguruan dan Ilmu Pendidikan Universitas Lampung dengan judul Gaya Bahasa pada Lirik Lagu dalam Lagu Gajah Karya Tulus dan Implikasinya Terhadap Pembelajaran Sastra di SMA.

\section{METODE PENELITIAN}

Jenis penelitian ini adalah deskriptif kualitatif. Deskriptif merupakan menggambarkan dari suatu objek yang akan dianalisis oleh penulis. "Deskriptif merupakan prosedur pemecahan masalah yang diselidiki dengan mendeskripsikan atau melukiskan keadaan subjek atau objek penelitian (syair) pada saat sekarang berdasarkan fakta-fakta yang tampak atau sebagaimana adanya" (Siswantoro, 2010: 56). Selain itu penelitian ini juga menggunakan pendekatan kualitatif. Subyek dalam penelitian ini adalah syair lagu Ebiet G. Ade sedangkan obyek dalam penelitian ini berupa gaya bahasa personifikasi yang diambil dalam syair lagu Ebiet G. Ade.

Teknik pengumpulan data merupakan cara penulis mengumpulkan suatu data yang digunakan dalam penelitian. Kualitas penelitian tergantung pada data penelitian. "Mengumpulkan data adalah satu pekerjaan penting dan sangat menentukan dalam suatu penelitian" (Ibrahim, 2015: 79). Terkumpulnya data penelitian merupakan salah satu keberhasilan seorang penulis yang harus dilakukan dalam penelitian. Pengumpulan data dalam penelitian ini menggunakan teknik dokumentasi dan studi literatur yang memfokuskan analisis gaya bahasa personifikasi dalam syair lagu Ebiet G. Ade.

\section{HASIL DAN PEMBAHASAN}

Berdasarkan penelitian yang dilakukan, diketahui hal-hal sebagai berikut. Gaya bahasa personifikasi yang terdapat di dalam syair lagu Ebiet G. Ade memiliki berbagai makna atau arti. Beberapa makna yang terdapat dalam syair lagu Ebiet G. Ade dalam penelitian ini yaitu makna yang menceritakan dan melambangkan kehidupan manusia, kehidupan alam, kehidupan beragama, kehidupan masyarakat, kehidupan politik dan percintaan. Terlihat pada syair lagu yang berjudul Rembulan Menangis pada syair tersebut terdapat gaya bahasa personifikasi yang melambangkan makna kehidupan masyarakat dan politik. Dari 3 album Ebiet G. Ade yang diteliti terdapat 47 kutipan gaya bahasa personifikasi. Kutipan-kutipan tersebut beberapa diantaranya sebagai berikut:

\section{(1.1) Lagu Aku Ingin Pulang}

\section{(1.1.1)kemanapun aku pergi bayang bayangmu mengejar}

Pada kutipan (1.1.1) tergambar seseorang yang merindukan kekasih hatinya yang telah lama tidak bertemu. Setelah ia pernah menyakiti hati kekasihnya tersebut, ia merasa sangat bersalah sehingga rasa bersalah itu seperti 
terus ada di dekatnya. Bayang-bayangmu mengejar kata bayang yang seolah-olah hidup ini mewakili seseorang yang selalu memikirkan kekasih hatinya, sehingga dapat disimpulkan makna yang terkandung dalam kutipan tersebut adalah makna cinta.

\section{(1.1.2) Aku mencari jawaban di laut}

Pada kutipan (1.1.2) ini, tergambar seseorang yang kebingungan mencari solusi atas kerinduannya terhadap kekasih hati yang pernah ia sakiti sehingga kemana pun dan seluas apapun ia pergi jawaban itu tidak akan pernah ia dapatkan. Kutipan jawaban di laut menunjukkan bahwa seolah-olah laut itu hidup sehingga ia bertanya kepada laut dan mencari jawaban atas solusi percintaanya terhadap kekasihnya. Makna yang terdapat pada kutipan ini yaitu makna cinta.

\section{(1.2) Lagu Berita Kepada Kawan}

\section{(1.2.1) Dihempas batu jalanan}

Kutipan (1.2.1) mengambarkan seseorang yang merasakan sakit di seluruh tubuhnya, sehingga hampir tumbang yang rasanya seperti dijatuhkan batu ketika melihat kampung halamannya yang dilanda bencana. Dihempas batu menunjukan bahwa batu dapat menghempaskan dirinya dalam syair ini. Makna yang terdapat pada kutipan ini yaitu makna kehidupan.

\section{(1.2.2) Bapak ibunya telah mati ditelan bencana tanah ini}

Kutipan (1.2.2) ini mengambarkan suasana saat kampung halamannya yang hancur dan kedua orang tua sahabatnya yang telah tiada diakibatkan terjadi bencana alam. Ditelan bencana tanah ini menunjukkan bahwa bencana seolah-olah hidup sehingga ia dapat menelan orang tua sahabatnya. Makna yang terdapat pada kutipan ini yaitu makna kehidupan.

\section{(1.2.3)Sesampainya di laut, kukabarkan semuanya, kepada karang kepada ombak, kepada matahari, tetapi semua diam, tetapi semua bisu.}

Kutipan (1.2.3) mengambarkan seseorang yang telah putus asa setelah melihat bencana yang terjadi di kampung halamannya sehingga ia seperti orang yang hilang akal dan bertanya kepada siapa saja yang ada di sekitarnya. Kutipan kukabarkan semuanya, kepada karang kepada ombak, kepada matahari, tetapi semua diam, tetapi semua bisu, menunjukan seolah-olah semuanya itu hidup sehingga ia dapat bercerita masalahnya kepada karang kepada ombak, kepada matahari. Makna yang terdapat di dalam kutipan ini yaitu makna kehidupan.

\section{(1.2.4) Coba kita bertanya pada, rumput yang bergoyang.}

Kutipan (1.2.4) mengambarkan seseorang yang sudah putus asa melihat alam yang semakin hancur dan tidak ada lagi orang yang bisa dijadikan tempat bercerita. Kutipan Bertanya pada rumput yang bergoyang menunjukan bahwa rumput itu seolah-olah hidup sehingga ia dapat bertanya kepada rumput. Makna yang terdapat pada kutipan ini yaitu makna kehidupan.

\section{(1.3) Lagu Cambuk Kecil}

\section{(1.3.1)Rasa panas membakar lahar dan badai menyapu bersih}

Kutipan (1.3.1) mengambarkan bencana yang telah terjadi atas kehendakNya. Bencana sesuai dengan apa yang dilakukan manusia di bumi ini. Agar bumi dapat bersih dari manusia yang 
berprilaku tidak baik. Kutipan badai menyapu bersih menunjukan seolah badai itu hidup dan mampu menyapu bersih. Makna yang terdapat pada kutipan ini kehidupan agama.

\section{(1.4) Lagu Kupu - Kupu Kertas}

\section{(1.4.1) Seperti angin tak pernah diam, selalu beranjak setiap saat menebarkan jala asmara,menaburkan aroma luka.}

Kutipan (1.4.1) mengambarkan seorang penghibur yang selalu ceria, terseyum dan tak pernah merasa sedih namun tindakannya tidak dapat di terima oleh masyarakat karna prilakunya tidak sesuai dengan norma yang ada. Kutipan angin tak pernah diam, selalu beranjak setiap saat menebarkan jala asmara menunjukan angin yang seolah hidup tak pernah diam selalu bergerak dan dapat menyebar asmara. Makna yang terdapat di dalam kutipan ini yaitu makna kehidupan.

\section{(1.4.2) Kupu-kupu kertas, yang terbang kian kemari}

Kutipan (1.4.2) mengambarkan seorang pekerja malam yang setiap hari selalu kesana kemari. Di sini kupu-kupu kertas diibaratkan sama dengan kupu-kupu malam. Kupu- kupu kertas yang terbang menunjukan seolah kupu- kupu kertas itu hidup padahal kupu-kupu kertas itu sebagai lambang PSK. Makna yang terdapat di dalam kutipan ini yaitu makna kehidupan.

\section{(1.4.3) Aku mengharapkan badai datanglah gemuruhnya akan melumatkan semua kupu-kupu kertas}

Kutipan (1.4.3) mengambarkan seseorang yang berharap musibah datang pada orang yang prilakunya tidak sesuai dengan norma seperti wanita penggoda. Agar wanita penggoda tersebut sadar akan prilaku dan dosanya. Kutipan badai datanglah gemuruhnya akan melumatkan sетиа kири-kири kertas menunjukkan seolah-olah badai itu hidup dan dapat menghancurkan PSK. Makna yang terdapat di dalam kutipan ini yaitu makna kehidupan.

\section{(1.5) Lagu Camelia 1}

\section{(1.5.1) Mengikuti arus air berlari}

Kutipan (1.5.1) mengambarkan bahwa hidup seorang wanita yang ia kagumi saat menjalani hidup. Wanita tersebut selalu mengikuti jalan yang telah ditetapkan seperti air mengalir seperti pasrah akan kehidupannya. Kutipan arus air berlari menunjukkan bahwa arus air yang seolah hidup dan dapat berlari. Makna yang terdapat di dalam kutipan ini yaitu makna cinta.

\section{(1.6) Lagu Menjaring Matahari}

\section{(1.6.1) Kabut, sengajakah engkau mewakili pikiranku}

Kutipan (1.6.1) menggambarkan pikiran seseorang yang sedang rumit dan gelap. Kabut dilambangkan sesuai dengan pikirannya yang sama-sama samar, suram atau kelam. Kabut, sengajakah engkau mewakili pikiranku menunjukan kabut seolah hidup dan dapat mengerti pikiran seseorang tersebut. Makna yang terdapat di dalam kutipan ini yaitu makna kehidupan.

\section{(1.6.2) Pekat, katamu peralat menyelimuti matahari}

Kutipan (1.6.2) menggambarkan keadaan kehidupan sekarang yang sangat tidak jelas, keras penuh dengan dosa dan salah. Pekat, katamu peralat menyelimuti 
matahari menunjukkan kata-kata pekat dapat mempengaruhi matahari dalam kutipan ini, pekat seolah-olah hidup. Makna yang terdapat dalam kutipan ini yaitu makna kehidupan agama.

\section{SIMPULAN}

Berdasarkan hasil analisis terhadap syair lagu Ebiet G. Ade, dapat ditemukan 47 jumlah gaya bahasa personifikasi yang terdapat pada kumpulan syair lagu Ebiet G. Ade. Gaya bahasa personifikasi dalam syair lagu Ebiet G. Ade terdapat pada syair lagu yang berjudul Aku Ingin Pulang, Berita Kepada Kawan, Cambuk Kecil, Camelia II, Kupu-kupu Kertas, Camelia I, Dosa Siapa, Nyanyian Kasmaran, Menjaring Matahari, Titip Rindu Buat Ayah, Apakah Ada Bedanya, Biarlah Aku Diam, Langit Terluka, Berjalan Diamdiam, Rembulan Menangis, Кири-kuрu Kertas, Masih Ada Waktu, Sketsa Rembulan Emas, Kalian Boleh Coba, Yogyakarta, Nyanyian Burung dan Pepohonan, Huru-hara. Gaya bahasa yang terdapat di dalam syair lagu Ebiet G. Ade memiliki berbagai macam makna seperti melambangkan kehidupan manusia, kehidupan alam, kehidupan beragama, kehidupan masyarakat, kehidupan politik dan percintaan. Dengan menggetahui makna yang terdapat di dalam syair lagu Ebiet G. Ade pembaca atau pendengar syair dapat mengerti akan pesan yang di sampaikan oleh pengarang syair.

\section{Rekomendasi}

Setiap karya sastra pasti bertujuan untuk menyampaikan suatu hal yang bermanfaat di dalam karyanya. Adapun saran penulis terhadap syair lagu Ebiet G. Ade di dalam penelitian ini yaitu:

1. Disarankan kepada para guru bahasa Indonesia untuk dapat menggunakan syair lagu sebagai media pembelajaran pelajaran gaya bahasa, agar siswa dapat lebih tertarik dan lebih berminat dalam proses belajarnya.

2. Disarankan kepada sastrawan agar terus menciptakan karya- karya yang memiliki makna positif sehingga generasi muda dapat termotivasi dengan syair-syair lagu yang bermakna positif.

3. Disarankan kepada pembaca bahwa makna gaya bahasa personifikasi yang terdapat dalam syair lagu Ebiet G. Ade dapat dijadikan pedoman dalam hidup.

\section{DAFTAR PUSTAKA}

Adriani M. Ermi (2009). Gaya Bahasa dalam Lirik Lagu. (Kajian Stilistika).

Ibrahim. (2015). Metodologi Penelitian Kualitatif. Bandung: Alfabeta.

Keraf, Gorys. (1985). Diksi dan Gaya Bahasa. Jakarta: Pustaka Utama.

Nurgiyantoro, Burhan. (2007). Teori Pengkajian Fiksi. Yogyakarta: Gadjah Mada University Press.

Siswantoro. (2010). Metode Penelitian Sastra. Yogyakarta: Pustaka Belajar.

Tarigan, Henry Guntur. (2013). Pengajaran Gaya Bahasa. Bandung: Angkasa Bandung.

Wahyuni, Ristri. (2014). Kitab Lengkap Puisi Prosa dan Pantun Lama. Yogyakarta: Saufa.

Waluyo, Herman J. (2005). Apresiasi Satra. Jakarta: Gramedia Pustaka Utama.

Wiyatmi. (2009). Pengantar Kajian Sastra. Yogyakarta: Pustaka. 